\title{
GAMBARAN KEINGINAN KELOMPOK LELAKI SEKS LELAKI DALAM MEMANFAATKAN KLINIK VOLUNTARY COUNSELLING AND TESTING DI PUSKESMAS CIPUTAT
}

\section{An Overview of the Intention of Men Sex with Men Groups in Utilizing Voluntary Counselling and Testing Clinic in Ciputat Public Health Center}

\author{
Kamila Rahmadiah ${ }^{1}$, Fajar Ariyanti ${ }^{1 *}$ \\ ${ }^{1}$ Program Studi Kesehatan Masyarakat, Fakultas Ilmu Kesehatan, Universitas Islam Negeri Syarif Hidayatullah \\ Jakarta \\ E-mail: fajar.ariyanti@uinjkt.ac.id
}

Naskah masuk 19 Juni 2020; review 22 Juni 2020; disetujui terbit 26 Juni 2020

\begin{abstract}
Background: Men Who Have Sex with Men (MSM) is a high-risk group of people getting infected with HIVIAIDS due to their multiple sexual partner behaviour and their anal intercourse practices. The MSM group is the highest risk factor for HIV new cases in Indonesia. The VCT (Voluntary Counselling and Testing) clinic is the main entrance to HIVIAIDS prevention, maintenance, support, and treatment services. However, the MSM group that utilizes VCT clinic in Ciputat subdistrict decreased from the previous year.

Objective: The purpose of this research was to thorouglhly identify about the overview of the intention of men who have sex with men groups in utilizing voluntary counselling and testing clinic in Ciputat public health center.

Method: This research was a descriptive qualitative research using the case study method, which was conducted in February-November 2019 in the working area of the Ciputat public health center. The main informants were homosexual or bisexual groups, who were selected by purposive sampling. Data validation used source triangulation, and data were analyzed by content analysis.

Result: The results showed that most of the informant had no intention to utilize the VCT clinic in Ciputat public health center, low knowledge of HIVIAIDS and VCT clinic, low susceptibility of perception and self-efficacy. All informants had barriers, high perception of severity, perception of good benefit, and quite large cues to act.

Conclusion: The majority of informants had no intention to utilize the VCT clinic due to low knowledge of HIV/AIDS and VCT clinic. Public health center and NGOs are recommended to collaborate in increasing knowledge of community on HIV/AIDS and VCT clinic.
\end{abstract}

Keywords: men who have sex with men, VCT clinic, HIV/AIDS

\begin{abstract}
Abstrak
Latar belakang: Lelaki Seks Lelaki (LSL) merupakan kelompok berisiko tinggi tertular HIV/AIDS dikarenakan kecenderungannya berganti pasangan dan melakukan seks anal. Kelompok LSL merupakan faktor risiko tertinggi kasus baru HIV di Indonesia. Klinik VCT (Voluntary Counselling and Testing) merupakan pintu masuk utama pada layanan pencegahan, perawatan, dukungan, dan pengobatan HIV/AIDS. Namun LSL yang memanfaatkan klinik VCT di Kecamatan Ciputat mengalami penurunan dari tahun sebelumnya.

Tujuan: Tujuan penelitian ini adalah untuk mengetahui secara mendalam mengenai gambaran keinginan kelompok LSL dalam memanfaatkan klinik VCT di Puskesmas Ciputat.

Metode: Penelitian ini merupakan penelitian kualititatif deskriptif dengan metode studi kasus, yang dilaksanakan pada Februari-November 2019 di wilayah kerja Puskesmas Ciputat. Informan utama adalah kelompok homoseksual maupun biseksual yang dipilih dengan cara purposive sampling. Validasi data menggunakan triangulasi sumber dan analisa data dilakukan dengan content analysis.

Hasil: Hasil penelitian menunjukkan sebagian besar informan belum memiliki keinginan untuk memanfaatkan klinik VCT di Puskesmas Ciputat, berpengetahuan kurang mengenai HIV/AIDS maupun klinik VCT, serta memiliki persepsi kerentanan dan efikasi diri yang rendah. Semua informan memiliki hambatan, persepsi keparahan yang tinggi, persepsi manfaat yang baik, serta isyarat untuk bertindak cukup besar.

Kesimpulan: Sebagian besar LSL belum memiliki keinginan untuk memanfaatkan klinik VCT. Hal ini karena informan memiliki pengetahuan yang kurang terkait HIV/AIDS maupun klinik VCT. Puskesmas dan LSM diharapkan dapat bekerja sama untuk dapat meningkatkan pengetahuan masyarakat mengenai HIV/AIDS dan klinik VCT.
\end{abstract}

Kata kunci: lelaki seks lelaki, klinik VCT, HIV/AIDS 


\section{PENDAHULUAN}

Lelaki Seks Lelaki (LSL) atau Men Who Have Sex With Men (MSM) adalah laki-laki yang berhubungan seksual dengan laki-laki. LSL merupakan populasi kunci atau kelompok berisiko tinggi tertular HIV/AIDS. HIV (Human Immunodeficiency Virus) adalah virus yang dapat merusak sistem kekebalan tubuh. Sedangkan AIDS (acquired immunodeficiency syndrome) adalah suatu kumpulan gejala berkurangnya kemampuan pertahanan diri yang disebabkan oleh masuknya virus HIV dalam tubuh seseorang. ${ }^{1}$ HIV/AIDS merupakan salah satu masalah serius di bidang kesehatan hingga sekarang, baik di negara maju maupun di negara berkembang.

Perilaku seksual yang dilakukan Lelaki Seks Lelaki (LSL) atau Men Who Have Sex With Men (MSM) tergolong berisiko, seperti tidak menggunakan kondom ataupun pelicin ketika melakukan seks anal, serta kecenderungan berganti pasangan dalam melakukan hubungan seks. Mardaniah (2018) dalam penelitiannya diketahui bahwa kelompok homoseksual berisiko 1,7 kali untuk terkena penyakit HIV/AIDS dibandingkan kelompok heteroseksual. Selain itu diketahui pula bahwa homoseksual yang berperilaku seksual dengan seks anal, partner seks lebih dari 1 orang, dan tidak memakai kondom memilki risiko 1 kali lebih besar terkena HIV/AIDS. ${ }^{2}$ Hal yang serupa juga didapatkan pada penelitian yang dilakukan Sidjabat (2017) bahwa beberapa faktor risiko yang berhubungan dengan kejadian HIV/AIDS pada kelompok LSL adalah tidak konsisten menggunakan kondom saat berhubungan seksual, dan mempunyai pasangan seksual lebih dari satu. ${ }^{3}$

Berdasarkan data penemuan kasus HIV yang dipublikasikan oleh UNAIDS, diketahui bahwa LSL merupakan faktor risiko tertinggi kasus baru HIV di Asia Pasifik pada tahun 2018 yaitu sebesar 30 persen. ${ }^{4}$ Hal serupa juga terjadi di Indonesia, bahwa LSL merupakan faktor risiko tertinggi kasus baru HIV pada tahun 2018 yaitu sebesar 20,4 persen. ${ }^{5}$ Salah satu provinsi di Indonesia yang mengalami peningkatan penemuan kasus baru HIV adalah Provinsi Banten. Pada tahun 2017 diketahui jumlah penemuan kasus baru HIV di Provinsi Banten adalah sebesar 1.315 kasus, lalu meningkat menjadi 1.334 kasus pada tahun 2018 dan meningkat signifikan menjadi 1.643 kasus di tahun $2018 .{ }^{6}$

Kota Tangerang Selatan yang merupakan salah satu wilayah di Provinsi Banten mengalami peningkatan signifikan terhadap penemuan kasus baru HIV. Pada tahun 2015 diketahui terdapat 104 kasus baru HIV, meningkat menjadi 155 kasus pada tahun 2016, dan meningkat tajam pada tahun 2017 menjadi 247 kasus. Faktor risiko HIV/AIDS di Kota Tangerang Selatan pada tahun 2011 - 2017 diketahui paling banyak terjadi pada LSL yaitu sebesar 310 kasus, lalu disusul oleh heteroseksual sebanyak 286 kasus dan penasun sebanyak 117 kasus. Dari tujuh kecamatan yang ada di Kota Tangerang Selatan, diketahui bahwa Kecamatan Ciputat merupakan wilayah dengan penemuan kasus HIV/AIDS tertinggi dari tahun 2011 - 2017 yaitu sebesar 180 kasus. $^{7}$

Berdasarkan laporan dari Puskesmas Ciputat diketahui terjadi peningkatan penemuan kasus baru HIV dari tahun 2016 dan 2017, yang juga diiringi dengan peningkatan faktor risiko LSL. Pada tahun 2016 terdapat 40 kasus baru HIV dengan faktor risiko LSL sebesar 18 kasus (45\%), lalu meningkat pada tahun 2017 menjadi 118 kasus baru HIV dengan faktor risiko LSL sebesar 90 kasus (76,27\%).

Salah satu upaya untuk menurunkan angka infeksi HIV dan AIDS adalah dengan dilakukannya pemeriksaan status HIV secara dini melalui program pelayanan klinik Voluntary Counselling and Testing (VCT). Klinik VCT/KTS (Konseling dan Testing Sukarela) yang merupakan pintu masuk utama pada layanan pencegahan, perawatan, dukungan, dan pengobatan HIV. ${ }^{1}$

*Korespondensi: fajar.ariyanti@uinjkt.ac.id

(C) Badan Penelitian dan Pengembangan Kesehatan ISSN: 2354-8762 (elektronik); ISSN: 2087-703X (cetak) 
Berdasarkan hasil studi pendahuluan diketahui terjadi penurunan signifikan terhadap jumlah LSL yang terjangkau oleh LSM Yayasan Kapeta dengan jumlah LSL yang mengakses layanan klinik VCT di Kecamatan Ciputat. Pada tahun 2017 diketahui LSL yang terjangkau dan memanfaatkan ayanan klinik VCT di Kecamatan Ciputat mencapai 99 persen, sedangkan pada tahun 2018 diketahui LSL yang terjangkau dan memanfaatkan layanan klinik VCT di Kecamatan Ciputat hanya mencapai 67,8 persen. Puskesmas Ciputat merupakan puskesmas yang ada di Kecematan Ciputat dan termasuk puskesmas pertama di Kota Tangerang Selatan yang memiliki layanan VCT dan tetap aktif hingga sekarang dengan jumlah kunjungan terbanyak dibandingkan puskesmas lainnya yang ada di wilayah Kota Tangerang Selatan.

Terdapat berbagai alasan yang menyebabkan LSL belum memanfaat klinik VCT, seperti kurangnya pengetahuan LSL terkait HIV/AIDS sehingga tidak mengetahui keparahan dari penyakit HIV/AIDS serta tidak meyadari bahwa dirinya berisiko tinggi tertular HIV, kurangnya pengetahuan terkait klinik VCT yang menyebabkan mereka tidak mengetahui manfaat atau pentingnya untuk melakukan tes HIV secara dini, belum merasakan gejala HIV, waktu yang tidak sesuai, takut mengetahui hasil tes kesehatannya, dan kurangnya dukungan tenaga kesehatan yang menyebabkan mereka belum memanfaatkan klinik VCT. Hal ini sesuai dengan penelitian terdahulu yang menyatakan bahwa persepsi kerentanan, persepsi keseriusan, persepsi manfaat, persepsi hambatan dan petunjuk bertindak memiliki korelasi dengan pemanfaatan VCT oleh LSL di LSM GAYa Nusantara. ${ }^{8}$ Hal yang sama juga didapatkan dalam penelitian Fibriana (2013) yang menyatakan bahwa terdapat beberapa faktor yang mendorong praktik pelanggan WPS melakukan VCT, antara lain persepsi kerentanan terkena HIV/AIDS, persepsi keparahan HIV/AIDS, persepsi manfaat VCT, persepsi hambatan melakukan VCT, serta isyarat dan motivasi melakukan VCT. ${ }^{9}$ Artikel ini adalah bagian dari penelitian mengenai gambaran keinginan kelompok LSL dalam memanfaatkan klinik VCT di Puskesmas Ciputat, yang mempunyai tujuan untuk mengetahui lebih dalam mengenai hal- hal yang mendasari keinginan LSL dalam memanfaatkan klinik VCT.

\section{METODE}

Jenis penelitian yang digunakan adalah penelitian kualitatif deskriptif dengan metode studi kasus. Penelitian ini dilakukan di wilayah kerja Puskesmas Ciputat pada bulan Februari November 2019. Variabel yang diteliti adalah karakteristik individu, pengetahuan HIVAIDS dan klinik VCT, persepsi kerentanan, persepsi keparahan, persepsi manfaat, persepsi hambatan, efikasi diri, isyarat untuk bertindak, dan keinginan dalam memanfaatkan klinik VCT.

Informan utama dalam penelitian ini adalah mereka yang terlibat langsung dalam objek yang diteliti, dengan kriteria inklusi: bertempat tinggal di wilayah kerja Puskesmas Ciputat, belum pernah mengunjungi klinik VCT di Puskesmas Ciputat, merupakan kelompok homoseksual maupun biseksual, serta bersedia untuk diwawancarai. Sedangkan kriteria ekslusi informan utama ialah informan yang membatalkan kesediaannya untuk diwawancarai, serta informan tinggal/bekerja di luar kota.

Cara penentuan informan tidak diarahkan pada jumlah tetapi berdasarkan asas kesesuaian dan kecukupan sampai mencapai saturasi data (titik jenuh). Informan dipilih dengan cara purposive sampling. Data yang digunakan dalam penelitian ini adalah data primer yang didapatkan dari wawancara mendalam pada informan. Instrumen yang digunakan untuk membantu pengumpulan data dalam penelitian ini adalah pedoman wawancara, alat pencatat serta alat perekam suara.Validasi data menggunakan triangulasi sumber, di mana informan pendukung adalah penanggung jawab klinik VCT Puskesmas Ciputat dengan pertimbangan informan tersebut mengetahui kondisi LSL walaupun tidak langsung berada di lapangan, dan informan kunci adalah petugas lapangan LSM Yayasan Kapeta dengan pertimbangan bahwa informan tersebut mengetahui dengan baik kondisi dan permasalahan LSL yang belum memanfaatkan klinik VCT. 
Analisis data yang dilakukan dalam penelitian ini terdiri dari tujuh tahap, dimulai dari transkripsi, pengenalan terhadap wawancara, pengkodean, mengembangkan kerangka analisis kerja, mengaplikasikan data ke kerangka analisis, memetakan data kedalam matriks kerangka kerja, dan menafsirkan data. ${ }^{10}$ Penelitian dilakukan setelah mendapatkan persetujuan etik Fakultas Ilmu Kesehatan UIN Syarif Hidayatullah Jakarta dengan nomor surat Un.01/F10/Kp.01.1/KE.SP/03.22.002/ 2019.

\section{HASIL}

\section{Karakteristik Informan}

Hasil penelitian menunjukkan bahwa seluruh informan berada pada rentang usia produktif, yaitu 15 - 54 tahun, di mana informan termuda berumur 18 tahun dan informan tertua berumur 32 tahun. Informan yang memiliki keinginan untuk memanfaatkan layanan klinik VCT berada pada masa dewasa awal (Tabel 1). Pekerjaan informan diketahui cukup bervariatif, terdiri dari pegawai swasta, pelayan restoran, buruh pabrik, dan pelajar/mahasiswa. Sebagian besar informan memiliki penghasilan setiap bulannya di bawah UMR Kota Tangerang Selatan atau di bawah Rp3.841.368. Hal ini dikarenakan pekerjaan yang sedang dijalani informan belum mampu membuatnya berada pada tahap untuk mendapatkan upah sesuai UMR Kota Tangerang Selatan.

Tabel 1. Karakteristik Informan Utama

\begin{tabular}{cclcc}
\hline Informan & $\begin{array}{c}\text { Umur } \\
\text { (Tahun) }\end{array}$ & Pekerjaan & $\begin{array}{c}\text { Penghasilan } \\
\text { (dalam } \\
\text { Rupiah) }\end{array}$ & $\begin{array}{c}\text { Keinginan } \\
\text { Memanfaatkan } \\
\text { KlinikVCT }\end{array}$ \\
\hline S1 & 18 & Pelayan restoran & 1,6 juta & Tidak \\
S2 & 30 & Buruh pabrik & 1,5 juta & Ya \\
S3 & 22 & Pelajar/Mahasiswa & 1,5 juta & Tidak \\
S4 & 28 & Pegawai swasta & 3,5 juta & Ya \\
S5 & 24 & Pegawai swasta & 4 juta & Tidak \\
S6 & 32 & Pegawai swasta & 4 juta & Tidak \\
\hline
\end{tabular}

\section{Pengetahuan Mengenai HIV/AIDS dan Klinik VCT}

Pengetahuan yang diteliti dalam penelitian ini adalah pengetahuan mengenai HIV/AIDS dan layanan klinik VCT. Berdasarkan hasil penelitian diketahui sebagian besar informan memiliki pengetahuan yang tergolong rendah terkait definisi HIV/AIDS, cara penularan HIV/AIDS dan cara pencegahan HIV/AIDS, sedangkan untuk gejala HIV/AIDS dan dampak HIV/AIDS pengetahuan informan sudah cukup baik.

\section{"Sudah pernah mendengar tentang HIV/AIDS, tapi ga tau}

kepanjangannya. HIV/AIDS itu penyakit yang sama mungkin ya." (S4)

"Penyebab HIV/AIDS karena gantiganti pasangan, terus oral seks, kalo lagi sariawan ga boleh. Dan katanya kalo udah kena penyakit kaya gitu ga boleh minum satu gelas gitu, pake handuk bareng gitu." (S2)

"Sebenarnya pencegahannya itu ya jangan seperti itu, maksudnya jangan laki ke laki ya, tapi hal itu kayanya mustahil, jadi seengganya menguranginya aja." (SI) 
"Gejalanya kaya semacam kencing nanah gitu, terus kaya kutil-kutil gitu. Kalo udah kena juga jadi sakit-sakit gitu, terus badannya kerenlah gitu jadi kurus. " (S2)

"Dampak jika terkena HIV adalah dijauhkan oleh masyarakat, terus jadi gampang sakit gitu, ga sembuhsembuh, parahnya ya kematian." (S3)

Sedangkan pengetahuan informan mengenai klinik VCT didapatkan hasil bahwa sebagian besar informan memiliki pengetahuan yang tergolong rendah mengenai definisi klinik VCT, sasaran klinik VCT, tempat klinik VCT, dan biaya klinik VCT, sedangkan pengetahuan mengenai kegiatan di klinik VCT sudah cukup baik.

"Klinik VCT belum pernah dengar, tapi kalo klinik tes HIV udah pernah." (SI)

"Klinik tes HIV itu untuk orang-orang seperti PSK gitu, terus kaya laki sama laki gitu juga."(S5)

"Klinik VCT terdapat di puskesmas. Untuk biaya yang harus dikeluarkan kurang tau." (S2)

"Klinik tes HIV itu ada di rumah sakitrumah sakit. Untuk biayanya ga tahu." (S4)

"Kegiatan yang dilakukan seperti pengambilan darah dan ada pemberian informasi edukasi."(S3)

\section{Persepsi Kerentanan Terhadap Penularan HIV}

Berdasarkan hasil penelitian diketahui bahwa informan yang memiliki keinginan untuk memanfaatkan klinik VCT adalah informan yang memiliki persepsi kerentanan yang tinggi terhadap penularan HIV, memiliki persepsi hambatan berupa rasa takut mengetahui hasil, memiliki efikasi diri yang baik, dan memiliki isyarat untuk bertindak berupa rasa takut terkena HIV/AIDS. Sebagian besar informan pada penelitian ini memiliki persepsi kerentanan yang rendah terhadap penularan HIV, bahkan terdapat informan yang tidak merasa rentan sama sekali. Hasil penelitian (Tabel 2) menunjukkan bahwa informan yang memiliki persepsi kerentanan yang rendah terhadap penularan HIV ataupun yang tidak merasa rentan sama sekali memiliki kecenderungan belum ada keinginan untuk mengakses klinik VCT. Sedangkan informan yang memiliki persepsi kerentanan yang tinggi cenderung memiliki keinginan untuk mengakses layanan klinik VCT.

\begin{abstract}
"Kemungkinan kena ada, tapi kecil, karena ga ganta-ganti pasangan, kita udah kaya bf gitu, terus juga sering make pengaman kan." (S5)
\end{abstract}

"Tidak merasa berisiko, karena selalu melakukan hubungan menggunakan pengaman dan melakukannya hanya pada satu orang yang sama." (S3)

\section{"Merasa berisiko karena masih sering melakukan hubungan tanpa pengaman." (S4)}

Hal ini didukung oleh pernyataan informan kunci yang menyatakan bahwa sebenarnya banyak LSL yang mengetahui dirinya berisiko terkena HIV/AIDS namun tidak peduli mengenai hal itu.

\section{"Rata-rata tau kalau dirinya berisiko, tapi gimana ya, kaya masa bodo gitu, mereka tau risikonya tapi ya gitu, dengan bermacam-macam alasan" (IK)}

\section{Persepsi Keparahan HIV/AIDS}

Persepsi informan terhadap tingkat keparahan penyakit HIV/AIDS adalah hampir sama, baik informan yang memiliki keinginan ataupun yang belum memiliki keinginan untuk mengakses layanan klinik VCT (Tabel 2). Adapun bentuk keparahan dari penyakit HIV/AIDS yang disebutkan informan ialah berupa penyakit yang dapat menyebabkan kematian, menyebabkan tubuh mudah terkena penyakit, dijauhi masyarakat, dapat menular ke keturunan, merupakan penyakit yang tidak bisa sembuh, dan dapat menyebabkan stres. 
Hal ini seperti yang diungkapkan oleh beberapa informan.

"Penyakit HIVIAIDS adalah penyakit
yang berbahaya karena dapat
menyebabkan kematian dan dapat
menular ke keturunan. Selain itu akan
dijauhkan oleh teman, keluarga,
semuanya." (SI)

"HIV/AIDS itu penyakit yang berbahaya soalnya kan bisa kematian ya. Dapat menyebabkan tubuh menjadi lemah sehingga gampang sakit. Jika mengetahui status dapat menyebabkan stres dan akan diajauhi dari orangorang sekitar, orangtua, teman, kecuali dari orang-orang LSM Kapeta.” (S2)

"HIV/AIDS adalah penykit yang berbahaya karena penyakit tersebut tidak akan bisa disembuhkan. Dampak yang paling parah adalah kematian, namun sebelum mencapai kematian, terlebih dahulu akan mudah terkena berbagai penyakit sehingga dapat menganggu aktifitas. Terus juga dijauhi oleh keluarga, orang-orang terdekat." (S3)

Tabel 2. Persepsi, Efikasi Diri, Isyarat untuk Bertindak dan Keinginan untuk Mengakses Klinik VCT

\begin{tabular}{|c|c|c|c|c|c|c|c|}
\hline Informan & $\begin{array}{c}\text { Persepsi } \\
\text { Kerentanan }\end{array}$ & $\begin{array}{c}\text { Persepsi } \\
\text { Keparahan }\end{array}$ & $\begin{array}{l}\text { Persepsi } \\
\text { Manfaat }\end{array}$ & $\begin{array}{c}\text { Persepsi } \\
\text { Hambatan }\end{array}$ & Efikasi Diri & Isyarat & Keinginan \\
\hline S1 & Sedikit & Tinggi & Baik & Waktu & Belum yakin & Orang lain & Tidak \\
\hline S2 & Sangat rentan & Tinggi & Baik & $\begin{array}{l}\text { - Waktu } \\
\text { - Takut hasil }\end{array}$ & Sudah yakin & $\begin{array}{l}\text { - Orang lain } \\
\text { - Media } \\
\text { - Rasa takut }\end{array}$ & $\mathrm{Ya}$ \\
\hline S3 & $\begin{array}{l}\text { Tidak sama } \\
\text { sekali }\end{array}$ & Tinggi & Baik & Rasa malu & Belum yakin & $\begin{array}{l}\text { - Orang lain } \\
\text { - Media }\end{array}$ & Tidak \\
\hline S4 & Rentan & Tinggi & Baik & Takut hasil & Sudah yakin & $\begin{array}{l}\text { - Orang lain } \\
\text { - Rasa takut }\end{array}$ & $\mathrm{Ya}$ \\
\hline S5 & Sedikit & Biasa & Baik & Waktu & Belum yakin & $\begin{array}{l}\text { - Orang lain } \\
\text { - Media }\end{array}$ & Tidak \\
\hline S6 & Sedikit & Tinggi & Baik & $\begin{array}{l}\text { - Waktu } \\
\text { - Takut jarum } \\
\text { suntik } \\
\text { - Alat tidak } \\
\text { steril }\end{array}$ & Belum yakin & $\begin{array}{l}\text { - Orang lain } \\
\text { - Media }\end{array}$ & Tidak \\
\hline
\end{tabular}

Berdasarkan hal tersebut diketahui bahwa hampir seluruh informan mengatakan HIV/AIDS adalah penyakit yang berbahaya karena dapat menyebabkan kematian.

\section{Persepsi Pemanfaatan Klinik VCT}

Informan yang memiliki keinginan ataupun yang belum memiliki keinginan untuk mengakses layanan klinik VCT mempunyai persepsi yang hampir sama terhadap manfaat dari klinik VCT. Adapun manfaat klinik VCT yang disebutkan informan adalah untuk mengetahui status kesehatan, untuk mendapatkan informasi, dan untuk mendapatkan penanganan segera. Berikut kutipan wawancara dengan informan yang menjelaskan hal tersebut:

"Klinik tes HIV adalah hal yang penting, biar tau status secepatnya, jadi kalo ternyata kenapa-napa bisa segera diobatin." (S4)

“Tes HIV adalah hal yang penting untuk mencegah hal yang tidak diinginkan di kemudian hari. Selain untuk cek kena 
HIV atau nggak, di klinik VCT juga dapat menambah pengetahuan seputar penyakit tersebut." (S6)

\section{Hambatan dalam Mengakses Klinik VCT}

Berdasarkan hasil penelitian diketahui bahwa informan yang memiliki keinginan untuk mengakses klinik VCT adalah informan yang memiliki hambatan berupa rasa takut akan hasil tes (Tabel 2). Sedangkan informan yang belum berkeinginan untuk mengakses klinik VCT sebagian besar memiliki hambatan dalam hal ketersediaan waktu, beberapa yang lain menyebutkan bahwa rasa malu dan rasa takutnya akan jarum suntik serta kesterilan alat yang digunakan merupakan hambatan yang juga dirasakannya.

"Kesulitannya itu ada di waktu, karena kerja malam, sedangkan setelahnya waktunya untuk istirahat kan. Selain itu ada rasa takut juga untuk tau hasil tesnya." (S2)

"Malu, karna kan klinik tes HIV itu kan klinik khusus untuk layanan HIV/AIDS." (S3)

"Takut dengan jarum suntik, takut diambil darahnya, takut alat yang digunakan ga steril segala macam gitu ya. Terus keterbatasan waktu juga karna kesibukan." (S6)

Berdasarkan hal tersebut dapat dikatakan bahwa sebagian besar informan memiliki hambatan mengenai waktu luang yang mereka miliki. Puskesmas Ciputat merupakan layanan kesehatan yang belum termasuk puskesmas rawat inap, sehingga tidak tersedia layanan 24 jam. Sedangkan informan kebanyakan mengalami kesulitan dalam menyediakan waktu luang untuk mengunjungi klinik VCT pada jam kerja puskesmas karena bersamaan dengan jam kerja informan.

\section{Efikasi Diri}

Informan yang memiliki efikasi diri yang baik cenderung berkeinginan untuk mengakses klinik VCT. Sedangkan informan yang memiliki efikasi diri yang rendah kecenderungannya belum memiliki keinginan untuk mengakses klinik VCT (Tabel 2). Sebagian besar informan memilki efikasi diri yang rendah dikarenakan hambatan yang ada dirasa sulit untuk dapat dihilangkan, seperti ketersediaan waktu, masih adanya rasa takut, dan rasa malu.

"Jika ada kesempatan/libur kerja, akan sangat mengusahakan untuk coba datang ke klinik VCT.” (S2)

"Untuk sekarang-sekarang ini masih sulit kayanya ya, karna kan kerjaan padat banget, jadi ga ada waktunya gitu." (S1)

"Belum siap untuk menghadapi rasa takut." (S6)

"Ga terlalu yakin, soalnya pandangan orang tentang klinik tes HIV masih negatif, yang buruk-buruk aja gitu, jadinya ga berani buat ke sana." (S3)

\section{Isyarat Mengakses Klinik VCT}

Hasil penelitian menunjukkan bahwa informan yang memiliki keinginan ataupun yang belum memiliki keinginan untuk mengakses layanan klinik VCT memiliki isyarat bertindak yang hampir sama untuk mengakses klinik VCT, hal ini karena informan memiliki rasa takut jika tertular HIV (Tabel 2). Isyarat untuk bertindak yang telah disebutkan oleh informan berasal dari orang lain, media informasi, dan rasa takut akan terkena HIV.

"Tahu tentang HIV/AIDS maupun klinik
VCT itu utamanya dari LSM Kapeta,
selain itu ada dari teman juga, ngobrol-
ngobrol secara langsung ataupun
obrolan dari grup chat whatsapp,
terkadang searching juga di google.
Sudah ada teman yang meninggal
dengan ciri-ciri HIV/AIDS, jadi ada
rasa khawatir juga gitu kira-kira kena
apa ngga, soalnya kan juga pernah
melakukan hubungan itu kan." (S2)




\section{Keinginan Mengakses Klinik VCT}

Keinginan untuk mengakses klinik VCT pada penelitian diketahui bahwa sebagian informan belum memiliki keinginan untuk mengakses klinik VCT karena merasa bahwa diri mereka sehat-sehat saja, sehingga berkunjung ke klinik VCT bukanlah hal yang harus mereka lakukan segera. Selain itu mereka beranggapan bahwa selama ini perilaku seksual yang mereka lakukan masih tergolong aman, sehingga mereka merasa aman dari ancaman HIV/AIDS. Sedangkan informan yang menyatakan berkeinginan untuk mengakses klinik VCT namun belum juga mengakses klinik VCT dikarenakan belum memiliki kesempatan untuk melakukannya.

\section{"Iya, mau bangat. Ya karna kan udah pernah ngelakuin hubungan itu kan, terus juga lingkungannya ga sehat. Jadi pengen bangat untuk cek." (S2)}

\section{"Gak ada sih. Karna kan sehat-sehat aja, terus juga selalu melakukan seks aman, jadi ga ada keperluan buat ke sana." (S3)}

\section{PEMBAHASAN}

Karakteristik informan pada penelitian ini terdiri dari umur, pekerjaan, dan penghasilan. Umur informan pada penelitian ini terbagi menjadi dua masa, yaitu masa remaja akhir dengan rentang umur $17-25$ tahun dan masa dewasa awal dengan rentang umur 26 - 35 tahun. Pada masa remaja diketahui bahwa rasa keingintahuan dan coba-coba sangatlah tinggi, di mana pada kebanyakan remaja tidak memikirkan risiko yang akan terjadi. Hal ini dapat menjadi sebab informan pada masa remaja akhir belum memiliki keinginan untuk memanfaatkan klinik VCT. Sedangkan pada masa dewasa awal diketahui terjadi perkembangan dalam kemampuan berpikir dan bertambahnya pengalaman, di mana dalam melakukan suatu tindakan sudah memikirkan dampak-dampak yang akan terjadi. Hal ini didukung oleh penelitian Marsofely (2016) yang menyatakan bahwa umur merupakan salah satu faktor yang dapat menggambarkan kematangan seseorang baik fisik, psikis maupun sosial, termasuk juga kematangan berpikir untuk mengambil keputusan. Di samping itu diketahui pula bahwa perubahan perilaku juga disebabkan karena proses pendewasaan. ${ }^{11}$

Selain itu Safitri (2012) dalam penelitiannya juga menjelaskan bahwa semakin muda umur seseorang menyebabkan mereka belum memikirkan efek dari penyakit HIV, dikarenakan masa terjadi transmisi dan penjalaran penularan HIV terjadi pada kurun waktu yang cukup lama, sehingga mereka belum memikirkan kondisi lain setelah dinyatakan positif HIV. Sedangkan semakin tua umur seseorang maka kecenderungan untuk melakukan pemeriksaan HIV juga semakin besar. ${ }^{12}$

Karakteristik informan yang kedua adalah pekerjaan. Pekerjaan ialah salah satu hal yang dibutuhkan seseorang untuk menjalani hidup, dengan melakukan suatu pekerjaan maka seseorang akan mendapatkan penghasilan untuk membiayai kebutuhannya sehari-hari, oleh karena itu bagi sebagian orang pekerjaan adalah hal yang sangat penting dalam hidupnya. Hasil penelitian ini menunjukkan bahwa hambatan yang dirasakan sebagian besar informan dalam mengakses klinik VCT adalah mengenai ketersedian waktu. Informan mengatakan bahwa jam layanan klinik VCT yang bertepatan dengan jam kerja informan membuat mereka kesulitan dalam mengakses VCT. Carmelita (2017) dalam penelitiannya menjelaskan bahwa pekerjaan membutuhkan suatu komitmen dari orang yang melakukannya. ${ }^{13}$ Pekerja dituntut untuk dapat memberikan waktu, tenaga, dan pikiran dalam mencapai hasil yang diinginkan oleh pekerjaan tersebut. Sehingga, dengan adanya tuntutan dalam pekerjaan, seseorang memiliki kesempatan yang terbatas untuk dapat meluangkan waktu dalam memanfaatkan layanan kesehatan.

Selain umur dan pekerjaan, karakteristik informan lainnya adalah penghasilan. Penghasilan merupakan salah satu hal yang berkaitan dengan tingkat status ekonomi seseorang. Penelitian ini menunjukkan bahwa baik informan yang memiliki penghasilan di bawah UMR maupun yang sudah mencapai UMR sama-sama belum mengakses klinik VCT. Hal ini diasumsikan karena gaya hidup yang dilakukan informan mengikuti tingkat status ekonominya. Seseorang yang berada 
pada status ekonomi yang rendah akan berusaha untuk mecukupkan kebutuhan sehariharinya sesuai dengan kemampuannya, sedangkan seseorang yang berada pada status ekonomi yang tinggi akan menaikkan standar kebutuhan hidupnya. Sehingga seseorang yang berada pada tingkat status ekonomi yang rendah maupun tinggi merasa bahwa penghasilan yang meraka dapatkan masih belum dapat memenuhi gaya hidup mereka. Oleh karena itu, pekerjaan yang menjadi sumber penghasilan menjadi prioritas dalam hidup mereka.

Berdasarkan hasil penelitian diketahui bahwa sebagian besar informan memiliki pengetahuan yang kurang terkait HIV/AIDS maupun klinik VCT. Hal tersebut dapat diasumsikan terjadi karena informasi yang informan miliki mengenai HIV/AIDS maupun klinik VCT masih sedikit. Informan seringkali mendapatkan informasi yang tidak lengkap mengenai HIV/AIDS maupun klinik VCT, walaupun informan pernah mendapatkan informasi dari orang-orang tertentu ataupun dari sosial media, namun biasanya informasi yang dipahami informan hanya pada bagian tertentu saja sehingga tidak memperluas pengetahuannya.

Pengetahuan seseorang dapat meningkat seiring dengan banyaknya informasi yang diterimanya, dan melalui pengetahuan tersebut dapat menimbulkan kesadaran pada diri seseorang hingga akhirnya orang tersebut dapat berperilaku sesuai dengan pengetahuan yang mereka miliki. ${ }^{14}$ Kurangnya pengetahuan informan terhadap penyakit HIV/AIDS maupun klinik VCT menyebabkan informan tidak menyadari kerentanan dirinya terkena HIV/AIDS dan pentingnya memanfaatkan klinik VCT sejak dini. Fatmala (2016) menjelaskan dalam penelitiannya bahwa pengetahuan dan pemahaman tentang faktor risiko HIV/AIDS terhadap LSL menimbulkan kesadaran pada diri LSL untuk melakukan berbagai pencegahan agar tidak terinfeksi HIV. Pemahaman ini yang menyebabkan LSL sukarela melakukan VCT. ${ }^{15}$

Hasil penelitian menunjukkan sebagian besar informan memiliki persepsi kerentanan yang rendah terhadap penularan HIV sehingga informan belum memiliki keinginan untuk mengakses klinik VCT. Sedangkan informan yang memiliki persepsi kerentanan yang tinggi cenderung memiliki keinginan untuk mengkases klinik VCT. Hal ini sesuai dengan teori HBM yang menyatakan bahwa persepsi kerentanan yang tinggi akan membuat seseorang mencari cara pencegahan agar tidak terkena penyakit tersebut, namun jika persepsi kerentanan seseorang rendah akan cenderung tidak mencari cara pencegahan dari suatu penyakit. ${ }^{16}$ Hal yang serupa juga didapatkan pada penelitian yang dilakukan Purwaningsih (2011) yang menjelaskan bahwasannya persepsi kerentanan adalah salah satu hal yang mendorong pemanfaatan VCT pada orang risiko tinggi HIV/AIDS di Puskesmas Dupak. $^{17}$

Rendahnya persepsi kerentanan yang dirasakan informan dikarenakan informan merasa sudah melakukan hubungan seks secara aman, seperti menggunakan kondom dan tidak berganti-ganti pasangan. Padahal belum tentu pasangannya melakukan hal yang sama, karena kelompok LSL pada umumnya memilki kecenderungan berganti-ganti pasangan dalam melakukan hubungan seksual. Sedangkan perihal penggunaan pengaman (kondom), diketahui bahwa hal tersebut tidak menjamin seseorang terhindar dari penularan HIV. Kondom memiliki pori-pori dengan kemampuan melindungi virus HIV hanya sebesar 46 persen sampai dengan 76 persen saja. Hal ini berarti masih terdapat peluang seseorang tertular HIV walaupun sudah menggunakan kondom. ${ }^{18}$

Tingginya persepsi keparahan HIV/AIDS yang disadari informan dapat diasumsikan karena informasi yang sering informan terima mengenai HIV/AIDS adalah mengenai keparahan dari penyakit tersebut. Walaupun informan memiliki persepsi bahwa HIV/AIDS adalah penyakit yang berbahaya, namun hal itu tidak lantas membuat informan untuk segera melakukan tindakan pencegahan agar terhindar dari penyakit tersebut. Besarnya persepsi keparahan namun tidak sejalan dengan tindakan pencegahan yang dilakukan bisa disebabkan karena berbagai hal, salah satunya karena tidak merasa bahwa dirinya berisiko terkena penyakit tersebut. Persepsi keparahan yang dirasakan terhadap HIV/AIDS berbeda pada masing-masing individu. Hal tersebut dikarenakan setiap orang memiliki pandangan yang subjektif terkait penyakit HIV/AIDS. ${ }^{8}$ 
Persepsi manfaat yang baik mengenai keberadaan klink VCT ternyata belum tentu membuat seseorang segera untuk memanfaatkannya. Berbeda dengan hasil penelitian yang dilakukan Purwaningsih (2011) yang menyatakan bahwa seseorang yang memiliki keyakinan yang kuat tentang manfaat VCT akan terdorong untuk melakukan VCT, sedangkan orang yang tidak percaya tentang manfaat VCT cenderung untuk tidak melakukan VCT. ${ }^{17}$ Hal ini diasumsikan dapat terjadi karena adanya hambatan-hambatan yang dialami sehingga menjadi penghalang informan untuk dapat memanfaatkan pelayanan kesehatan yang

Sedangkan, informan yang memiliki persepsi hambatan berupa rasa malu berkunjung ke klinik VCT dikarenakan masih kentalnya stigma atau pandangan negatif masyarakat kepada pengguna layanan VCT, seperti dilabeli jika orang yang mengkases klinik VCT adalah orang yang terkena HIV dan memiliki perilaku yang buruk yang dianggap tidak sesuai atau bertentangan dengan norma dalam masyarakat. ${ }^{20}$ Selain itu diketahui bahwa informan yang memiliki hambatan berupa rasa takut mengetahui hasil tes merupakan informan yang memiliki keinginan untuk pergi ke layanan klinik VCT. Hal ini bisa jadi karena informan memilliki isyarat untuk bertindak berupa adanya kabar temantemannya yang terkena penyakit dengan ciriciri HIV/AIDS.

Sebagian besar informan memiliki efikasi diri yang rendah dengan kecenderungan belum berkeinginan untuk mengakses klinik VCT, hal ini dikarenakan hambatan-hambatan yang belum mampu dilalui, seperti ketersediaan waktu, rasa takut, dan rasa malu. Sedangkan informan yang memiliki efikasi diri yang baik cenderung berkeinginan untuk mengakses klinik VCT. Hal serupa juga ditemukan dalam penelitian yang dilakukan oleh Enggarwati (2015), yang mana dalam penelitiannya didapatkan hasil bahwa efikasi diri yang tinggi mendorong waria pekerja seks di Kabupaten Kudus untuk melakukan perilaku pencegahan HIV/AIDS. $^{21}$

Informan memiliki isyarat untuk bertindak yang cukup besar, yang terdiri dari orang lain dan media informasi. Isyarat untuk bertindak yang cukup besar ternyata belum mampu mendorong informan untuk memanfaatkan tersedia. Sebagian besar informan memiliki hambatan mengenai waktu luang yang mereka miliki. Hal ini sejalan dengan penelitian yang dilakukan oleh Risqi (2018) yang menyatakan bahwa adanya keterbatasan jam pelayanan VCT khususnya untuk populasi kunci yang hanya beroperasi pada hari tertentu dari pukul 12.00-14.00 WIB merupakan salah satu penyebab dari menurunnya jumlah kunjungan VCT di Puskesmas Duren, Semarang..$^{19}$ Maka, salah satu hal yang dapat dilakukan mengenai hal ini adalah dengan melakukan advokasi dan kerja sama dengan Puskesmas Ciputat agar layanan VCT dapat dilaksanakan pada akhir pekan atau bukan hari aktif kerja.

layanan VCT diasumsikan karena informan belum merasa berisiko untuk terkena HIV/AIDS, sehingga menurutnya berkunjung ke klinik VCT bukanlah hal yang harus dilakukannya sesegera mungkin. Selain itu adanya beberapa hambatan yang dialami juga bisa menjadi hal yang membuat informan belum memanfaatkan layanan klinik VCT. Sedangkan, informan yang mempunyai isyarat untuk bertindak berupa rasa takut terkena HIV ternyata memiliki keinginan untuk memanfaatkan klinik VCT. Hal ini dikarenakan informan mendapatkan kabar bahwa teman di lingkungannya yang pernah melakukan hal yang sama menderita penyakit dengan gejala HIV/AIDS, sehingga informan khawatir adanya kemungkinan dirinya terkena HIV/AIDS.

Rendahnya keinginan seseorang berbanding lurus dengan perilakunya yang belum memanfaatkan layanan kesehatan, umumnya Ia merasa bahwa hal itu tidak diperlukan. Terdapat beberapa hal yang dapat mendasari perilaku tersebut, selain karena informan merasa bahwa dirinya sehat-sehat saja dan tidak berisiko terkena HIV, bisa juga dikarenakan tidak dipungutnya biaya untuk mengakses klinik VCT di puskesmas, sehingga informan merasa bahwa untuk mengakses klinik VCT bisa dilakukan nanti-nanti saja jika informan merasa sudah benar-benar membutuhkannya, atau ketika informan sudah merasakan gejala-gejala pada tubuhnya.

Selain itu pemikiran masyarakat yang masih mengutamakan pengobatan daripada pencegahan juga merupakan salah satu hal yang dapat menyebabkan minimnya tindakan pencegahan yang dilakukan, masyarakat 
cenderung mencari pengobatan (layanan kesehatan) ketika dirinya sudah terkena suatu penyakit. Sedangkan, informan lainnya yang memilki keinginan untuk mengakses klinik VCT dikarenakan rasa takut terkena HIV/AIDS karena pernah melakukan hubungan seksual yang tidak aman, serta merasa khawatir karena tinggal di lingkungan yang kurang baik. Walaupun hingga saat ini mereka belum berkesempatan untuk berkunjung ke klinik VCT karena terdapat beberapa hambatan yang mereka alami, namun mereka menyatakan jika suatu saat ada peluang akan segera berkunjung ke klinik VCT. Keterbatasan dalam penelitian ini adalah triangulasi sumber yang tidak dapat dilakukan karena tidak semua informan LSL dapat bersama dengan pasangannya dan tidak semua pasangan bersedia untuk menjadi informan penelitian.

\section{KESIMPULAN}

Bahaya dari HIV/AIDS yang disebutkan LSL adalah dapat menyebabkan kematian, tubuh menjadi mudah terkena penyakit, dapat menular ke keturunan, penyakit yang tidak bisa sembuh, dapat menyebabkan stres, dan dijauhi oleh masyarakat.

Semua LSL memiliki persepsi manfaat yang baik mengenai klinik VCT yaitu untuk mengetahui status kesehatan, mendapatkan informasi dan edukasi, mendorong pola hidup sehat, serta mendapatkan penanganan segera. Hambatan yang dirasakan LSL berupa ketersediaan waktu, rasa takut mengetahui hasil tes, rasa takut akan jarum suntik dan kesterilan alat, serta rasa malas dan rasa malu. Isyarat untuk bertindak yang dialami LSL yang dapat memperkuat keputusannya untuk memanfaatkan layanan klinik VCT sudah cukup baik, terdiri dari orang lain, media informasi, dan rasa takut terkena HIV.

\section{SARAN}

Petugas klinik VCT di Puskesmas maupun petugas Lembaga Swadaya Mayarakat diharapkan dapat memperluas dan memperbanyak informasi kepada kelompok LSL mengenai HIV/AIDS dan klinik VCT baik melalui media cetak, media elektronik, maupun kegiatan seperti penyuluhan dan seminar.

Diharapkan kepada peneliti selanjutnya untuk dapat mengkaji lebih dalam mengenai LSL dalam memanfaatkan klinik VCT menggunakan pendekatan metodologi kualitatif yang lebih komprehensif atau menggunakan metode kuantitatif sehingga data yang diperoleh dapat digeneralisasi pada seluruh populasi.

\section{UCAPAN TERIMA KASIH}

Ucapan terima kasih disampaikan kepada Puskesmas Ciputat dan LSM Yayasan Kapeta.

\section{DAFTAR PUSTAKA}

1. Kementerian Kesehatan RI. Peraturan Menteri Kesehatan RI Nomor 74 Tahun 2014 Tentang Pedoman Pelaksanaan Konseling Dan Tes HIV.; 2014.

2. Mardaniah LH, Jumakil. Risiko Faktor Orientasi Seksual Terhadap Kejadian HIV/AIDS Berdasarkan Perilaku Seksual, Narkoba Parenteral, dan Riwayat IMS di Kota Kendari Tahun 2017. J Ilm Mhs Kesehat Masy. 2018;3(2).

3. Sidjabat FN, Setyawan H, Sofro MA, Hadisaputro S. Lelaki Seks Lelaki, HIV/AIDS dan Perilaku Seksualnya di Semarang. $J$ Kesehat reproduksi. 2017;8(2):131-142.

4. UNAIDS. UNAIDS Data 2019. Switzerland: Join United Nations Programm on HIV/AIDS; 2019.

5. Kementerian Kesehatan RI. Profil Kesehatan Indonesia 2018. Jakarta; 2019.

6. Kementerian Kesehatan RI. Data Dan Informasi Profil Kesehatan Indonesia 2019. Jakarta; 2020.

7. Dinas Kesehatan Kota Tangerang Selatan. Profil Dinas Kesehatan Kota Tangerang Selatan Tahun 2017. Tangerang Selatan; 2018.

8. Prawesti N., Purwaningsih, Armini NKA. Faktor Pendorong Pemanfaatan Layanan Voluntary Counselling and Testing (VCT) oleh Lelaki Suka dengan Lelaki 
(LSL) di LSM GAYa Nusantara. J ners dan kebidanan. 2018;5(2):129-135.

9. Fibriana A. Keikutsertaan Pelanggan Wanita Pekerha Seks dalam Voluntary Counseling and Testing (VCT). J Kesehat Masy. 2013;8(2):161-165.

10. Gale NK, Heath G, Cameron E, Rashid S, Redwood S. Using The Framework Method for The Analysis of Qualitative Data in Multi-Disiplinary Health Research. BMC Med Res Methodol. 2013;13(117).

11. Marsofely RL, Yuniarti MWA. Praktik Waria dalam Melakukan Voluntary Counseling and Testing (VCT). J Media Kesehat. 2016;9(2):114-203.

12. Safitri N. Faktor-Faktor yang Berhubungan dengan Niat untuk Memilih Pelayanan Rawat Inap di rumah Sakit Bogor Medical Center Tahun 2011. 2012.

13. Carmelita D., Shaluhiyah Z, Cahyo K, PP N. Analisis Faktor-Faktor yang Berhubungan dengan Praktik Skrining IMS oleh Lelaki Seks Lelaki (LSL) Sebagai Upaya Pencegahan Penularan HIV (Studi Kasus pada Semarang GAYa Community). J Kesehat Masy. 2017;5(3):486-494.

14. Notoatmodjo S. Kesehatan Masyarakat: Ilmu Dan Seni. jakarta: Rineka Cipta; 2011.
15. Fatmala D. Faktor Predisposing, enabling, dan Reinforcing dalam pemanfaatan VCT oleh Laki-laki seks dengan laki-laki (LSL). J Berk Epidemiol. 2016;4(1):138-150.

16. Sarafino EP, Smith T. Health Psychology: Biopsychosocial Interaction. USA: John Wiley adn Sons, Inc; 2011.

17. Purwaningsih, Misutarno, Siti N. Analisis Faktor Pemanfaatan VCT Pada Orang Risiko Tinggi HIV/AIDS. J ners dan kebidanan. 2011;6(1):58-67.

18. Fauziyah R. Perilaku Berisiko pada Lelaki Seks Lelaki Terhadap Kejadian Human Immunodeficiency Virus di Indonesia (Data Survei Terpadu Biologis dan Perilaku Tahun 2015). 2018.

19. Risqi N, Wahyono B. Program Pelayanan Voluntary Counseling and Testing (VCT) di Puskesmas. Higeia J Public Heal Res Dev. 2018;2(4):564-576.

20. Nugroho C, Kusumaningrum TAI. Isyarat Bertindak Sebagai Faktor Pendorong Lelaki Seks Lelaki dalam Melakukan VCT. J promosi Kesehat Indones. 2018;13(2):101-113.

21. Enggarwati I. Faktor-Faktor Yang berhubungan dengan perilaku pencegahan penularan HIV/AIDS pada waria pekerja Seks di Kabupaten Kudus Tahun 2015. 2015. 